\title{
Analisis Persepsi Anggota dalam Memilih Produk pada KSU Mikat Al Khidmah Purworejo
}

\author{
Dini Zanuar Wulandari, Agus Fitri Yanto*
}

Politeknik Sawunggalih Aji - Kutoarjo

*Email: agusfitri2011@gmail.com / agusfy@polsa.ac.id

\begin{abstract}
Abstrak
KSU Mikat Al Khidmah adalah Koperasi Serba Usaha bidang jasa keuangan syariah di Purworejo. Untuk mendapatkan dan mempertahankan anggota, Mikat Al Khidmah menerapkan strategi pemasaran secara optimal karena persaingan antar lembaga sejenis yang semakin tinggi, khususnya pada produk simpanan. Oleh karena itu perlu diketahui bagaimana pengaruh kualitas produk, harga, dan promosi dalam memilih produk simpanan. Metode pengumpulan data yang digunakan adalah wawancara, observasi, kuesioner dan studi pustaka. Pada analisis regresi linier berganda yaitu $Y=-0,502+0,610 X 1+$ $0,112 X 2+0,350 X 3+\varepsilon$, hasil analisis menunjukkan $R$ Square 0,636, yang berarti 60\% variabel persepsi anggota dapat dijelaskan oleh kualitas produk, harga dan promosi. Hasil uji-t menunjukkan bahwa kualitas produk berpengaruh signifikan positif terhadap persepsi anggota memilih produk simpanan. Sedangkan harga tidak berpengaruh signifikan dan negatif terhadap persepsi anggota dalam memilih produk simpanan. Sedangkan promosi berpengaruh signifikan dan positif terhadap persepsi anggota. Berdasarkan uji $F$ diketahui bahwa secara bersama-sama variabel kualitas produk, harga dan promosi berpengaruh positif dan signifikan terhadap persepsi anggota memilih produk simpanan.
\end{abstract}

Kata Kunci : Harga, Kualitas produk, KJKS, Promosi

\section{PENDAHULUAN}

Koperasi Indonesia merupakan alat pembangunan masyarakat yang berlandaskan Pancasila dan Undang-Undang Dasar 1945. Dalam perekonomian nasional, koperasi mendapat tempat strategis sesuai dengan Undang-Undang Dasar 1945 pasal 33 ayat 1 yang menyatakan bahwa perekonomian disusun sebagai usaha atas asas kekeluargaan. Oleh karenanya pengembangan dan pemberdayaan koperasi harus mencerminkan nilai dan prinsip sebagai wadah usaha bersama untuk memenuhi aspirasi dan kebutuhan ekonomi anggota. Hal ini akan menjadikan koperasi tumbuh kuat, sehat, mandiri, dan tangguh dalam menghadapi perkembangan ekonomi nasional maupun global yang semakin dinamis dan penuh tantangan. Koperasipun dituntut untuk mempertinggi taraf hidup anggotanya, meningkatkan produksi dan mewujudkan pendapatan yang adil dan kemakmuran yang merata.

Secara umum landasan koperasi merupakan pedoman dalam menentukan arah, tujuan, peran serta kedudukan koperasi terhadap pelaku-pelaku ekonomi lainnya di dalam sistem perekonomian Indonesia (Subandi, 2013: 21). Koperasi merupakan badan usaha yang mengorganisir pemanfaatan dan pendayagunaan sumber daya ekonomi para anggotanya atas dasar prinsip-prinsip koperasi dan kaidah usaha ekonomi untuk meningkatkan taraf hidup anggota pada khususnya dan masyarakat daerah kerja pada umumnya.

Dengan demikian, koperasi merupakan gerakan ekonomi rakyat dan sokoguru perekonomian nasional (Rudianto, 2010: 3). Pada dasarnya koperasi mempunyai tujuan untuk meningkatkan taraf hidup anggotanya dan masyarakat pada umumnya melalui wadah perkoperasian. Koperasi juga mempunyai tujuan yang sama dengan lembaga keuangan lain yakni untuk mendapatkan keuntungan. Keuntungan yang diperoleh koperasi bukan melalui bunga melainkan bagi hasil yang telah disepakati antara pihak koperasi dengan anggotanya, Oleh karena itu, keberadaan anggota dalam usaha ini sangat berperan penting. Persepsi pemasar yang diasumsikan oleh anggota yang sudah bergabung dalam koperasi mengenai produk yang ditawarkan merupakan salah satu faktor pemasar koperasi. Hal ini didukung oleh pendapat Nitisusastro (2013: 196) bahwa " Sub-faktor yang berupa upaya para pemasar perusahaan (firms marketing effort) yang bertujuan untuk mempengaruhi konsumen agar membeli produk-produk perusahaan yang dipasarkan".

Di dalam pemasaran jasa termasuk koperasi, ada beberapa upaya yang dapat dilakukan untuk mempengaruhi keputusan anggota. Diantaranya adalah produk, harga, promosi, dan presepsi. 
Masing-masing komponen tersebut perlu pengoorganisasian maksimal untuk mendapatkan target usaha sesuai dengan harapan. Hal ini berlaku pula pada Koperasi Mikat Al Khidmah Purworejo.

Koperasi Mikat Al Khidmah Purworejo merupakan salah satu Koperasi Serba Usaha (KSU) yang terletak di Jalan KH. Wahid Hasyim No.17 Purworejo. Dalam melakukan usahanya guna mendapatkan dan mempertahankan anggota tidak terlepas dari pemasaran. Koperasi memiliki beberapa produk yang dapat dipilih oleh para anggota, diantaranya SIMULA, simpanan Qurban, simpanan Mabrur, dan simpanan Karomah. Beberapa jenis simpanan, simpanan yang paling banyak diminati oleh para anggota adalah SIMULA, sejenis tabungan pada umumnya namun memiliki setoran awal yang terjangkau, dapat diambil sewaktu-waktu, bebas biaya bulanan, dan tidak ada potongan. Untuk sistem penabungannya dilakukan dengan dua cara yaitu anggota datang langsung atau marketing koperasi mendatangi anggota di tempat yang telah disepakati. Jangka waktu pengambilan simpanan tidak terikat, jadi bisa diambil dalam tempo harian, mingguan, maupun bulanan.

Dalam kegiatan operasionalnya, Koperasi Mikat Al Khidmah Purworejo sudah menggunakan sistem komputerisasi untuk lebih mempermudah pelayanan kepada anggota. Namun juga masih menggunakan sistem manual untuk mem-back up data-data yang ada. Produk koperasi sebenarnya beragam dan sesuai dengan pangsa pasar yang dituju. Akan tetapi belum banyak masyarakat yang tahu sehingga setiap pemasar menawarkan produk, banyak penolakan dari masyarakat. Padahal harga yang ditawarkan dapat dijangkau untuk masyarakat kalangan menengah kebawah. Hanya saja untuk bagi hasil yang diberikan oleh koperasi kepada anggota tidak tetap dan tergantung pendapatan koperasi tiap bulannya.

Di sisi lain kegiatan promosi pada koperasi sangat minim. Promosi hanya dilakukan melalui sosialisasi dari mulut ke mulut (mouth advertising) dan door to door. Mouth advertising yang dimaksud adalah promosi yang dilakukan melalui perantara satu orang dan disebarluaskan oleh satu orang ke orang lain. Sejauh ini tidak ada promosi konvensional khusus seperti dengan pembuatan banner, iklan di radio, iklan di surat kabar dan lainnya yang dilakukan oleh pihak koperasi.

KSU Mikat Al Khidmah merupakan salah satu lembaga di bawah naungan Nahdlatul Ulama. Oleh karena itu, dalam setiap event besar ada karyawan dari lembaga yang sosialisasi mengenai produk-produk yang ada. Jika ada yang berminat untuk menjadi anggota, maka langsung dapat melakukan pendaftaran dan mengisi registrasi di tempat yang selanjutnya akan segera diproses di kantor. Dengan cara promosi yang demikian masih ada sebagian masyarakat yang belum paham dengan keberadaan koperasi, sehingga pemasar masih kesulitan dalam mencari calon anggota selain dalam acara-acara yang di bawahi oleh Nahdlatul Ulama, Oleh karena itu persepsi anggota mengenai produk koperasi, harga dan promosi merupakan faktor yang sangat penting untuk menarik anggota agar bergabung. Berdasarkan hasil penelusuran yang diperoleh, maka perlu diketahui lebih jauh sejauh mana faktor kualitas produk, harga, dan promosi mempengaruhi persepsi anggota dalam memilih produk Simpanan pada KSU Mikat Al Khidmah Purworejo, khususnya kualitas produk, harga, dan promosi.

\section{METODE PENELITIAN}

Variabel yang digunakan penulis dalam penelitian ini adalah dimensi variabel kualitas produk, harga, dan promosi. Populasi penelitian ini meliputi semua anggota Simpanan pada KSU Mikat Al Khidmah Purworejo yakni sebanyak 2.800 orang. Sedangkan sampel dari penelitian ini sebanyak 80 anggota dari semua anggota Simpanan yang ada pada KSU Mikat Al Khidmah Purworejo. Penelitian ini menggunakan jenis sampel random sampling, dimana teknik samping dipilih secara acak.

Metode analisis yang digunakan yaitu uji regresi linear berganda untuk mengetahui seberapa besar pengaruh produk, harga dan promosi terhadap persepsi konsumen dalam memilih produk simpanan SIMULA.

$$
\mathrm{Y}=\mathrm{a}+\mathrm{b}_{1} \mathrm{X}_{1}+\mathrm{b}_{2} \mathrm{X}_{2}+\mathrm{b}_{3} \mathrm{X}_{3+} \varepsilon
$$

$$
\text { Keterangan: }
$$

$$
\begin{array}{ll}
\mathrm{Y} & =\text { Persepsi konsumen } \\
\mathrm{a} & =\text { Konstanta }
\end{array}
$$

$\mathrm{X}_{1} \quad=$ Nilai variabel produk

$\mathrm{X}_{2} \quad=$ Nilai variabel harga 


$\begin{array}{lll}\mathrm{b}_{1} & =\text { Koefisien variabel produk } & \mathrm{X}_{3}=\text { Nilai variabel promosi } \\ \mathrm{b}_{2} & =\text { Koefisien variabel harga } \varepsilon & =\text { Eror } \\ \mathrm{b}_{3} & =\text { Koefisien variabel promosi } & \end{array}$

Untuk mengukur produk, harga dan promosi menggunakan skala likert. Menurut Sugiyono (2009:93), dengan menggunakan skala likert maka variabel yang akan diukur dijabarkan menjadi indikator variabel. Indikator tersebut dijadikan sebagai titik tolak untuk menyusun item-item instrumen yang dapat berupa pernyataan / pertanyaan. Jawaban setiap item instrumen bergradasi dari sangat positif sampai sangat negatif, sebagai berikut :
a. Sangat setuju
b. Setuju
c. Ragu-ragu
d. Tidak Setuju
e. Sangat Tidak Setuju

\section{HASIL DAN PEMBAHASAN}

Pemasaran merupakan salah satu faktor penting dalam siklus yang bermula dan berakhir dengan kebutuhan. Seorang pemasar harus bisa menafsirkan kebutuhan dan keinginan konsumen, mempromosikan produk secara efektif, serta mengkombinasikannya dengan data pasar seperti lokasi konsumen, jumlah dan keseluruhan konsumen. Dari beberapa pendapat diketahui bahwa pemasaran merupakan proses kegiatan yang dilakukan oleh seseorang atau kelompok untuk memperoleh yang mereka inginkan melalui penciptaan dan pertukaran produk dan nilai yang dipengaruhi oleh faktor sosial, budaya, politik, ekonomi, dan manajerial. Di dalamnya terdapat strategi yang disebut bauran pemasaran (marketing mix) yang berperan penting dalam mempengaruhi konsumen agar dapat membeli produk atau jasa yang ditawarkan.

Menurur Suharno \& Sutarso (2010: 8) strategi pemasaran adalah kerangka kerja jangka panjang yang memandu seluruh aktivitas teknis dalam pemasaran dimana didasarkan kepada semangat untuk memenuhi kebutuhan pelanggan. Di dalamnya mencakup lima alternatif filosofi untuk menjalankan strategi pemasaran yaitu sebagai berikut :

1. Konsep Produksi, memberikan orientasi bahwa keberhasilan kegiatan pemasaran akan ditentukan oleh sejauh mana pemasar bisa memproduksi sebanyak-banyaknya dan mendistribusikan seluas-luasnya.

2. Konsep Produk, berorientasi bahwa pemasar akan berhasil jika bisa membuat produk dengan kualitas yang baik sesuai keinginan konsumen.

3. Konsep Penjualan, pemasar yang berhasil akan ditentukan sejauh mana mampu mempromosikan dan menjual produk.

4. Konsep Pemasaran, memberikan tuntutan lebih aktif pada pemasar. untuk menemukan kebutuhan dan keinginan konsumen dan memberikan penawaran yang memuaskan dan lebih baik dari pesaing.

5. Konsep Pemasaran Sosial, pemasar berfokus pada konsumen dan melihat aspek lingkungan, menunjukkan kepedulian dan tanggung jawab sosial.

Produk merupakan titik pusat dari kegiatan pemasaran karena merupakan hasil perusahaan yang dapat ditawarkan ke pasar untuk di konsumsi dan merupakan alat untuk mencapai tujuan dari perusahaan. Produk harus memiliki keunggulan dari yang lain, baik segi kualitas, desain, bentuk, ukuran, kemasan, pelayanan, garansi, dan rasa agar dapat menarik minat konsumen untuk mencoba dan membeli produk tersebut.

Kotler \& Armstrong (Ginting, 2011 : 90) mendefinisikan produk sebagai segala sesuatu yang dapat ditawarkan ke pasar untuk perhatian, akuisi, penggunaan dan konsumsi yang dapat memuaskan keinginan atau kebutuhan. Bahkan perusahaan tidak lagi bersaing dalam produk yang dihasilkan saja, tetapi bersaing dalam aspek tambahan pada produknya seperti aspek pembungkus, service, iklan dan faktor-faktor lainnya yang dapat menguntungkan konsumen.

Harga juga dianggap sebagai imbalan berupa pembayaran yang diterima karena telah menyerahkan suatu produk barang atau jasa kepada konsumen (Nitisusastro, 2013: 199). Dengan kata lain harga merupakan imbalan berupa uang yang dibayarkan untuk memperoleh produk jasa atau barang yang diinginkan konsumen. 
Memilih strategi harga berarti menentukan bagaimana harga akan didasarkan, agar harga menjadi keunggulan kompetitif bagi perusahaan. Strategi harga dapat dilakukan melalui beberapa pendekatan yaitu (Suharno \& Sutarso, $2010: 183$ ) :

1. Strategi harga berdasarkan biaya, yang melihat aspek biaya sebagai penentu harga. Pendekatan yang sering digunakan adalah cost plus pricing yaitu penetapan harga dengan menjumlah semua biaya dan ditambahkan jumlah keuntungan tertentu.

2. Strategi harga berdasarkan permintaan, mendasarkan harga pada estimasi volume penjualan yang dapat dijual berdasarkan pada pasar tertentu dengan harga tertentu. Teknik yang digunakan adalah target costing (identifikasi kualitas dan fungsi yang dibutuhkan) dan yield management pricing (menentukan harga berbeda pada pelanggan yang berbeda)

3. Strategi harga berdasarkan persaingan, menjadikan pesaing sebagai titik tolak penetapan harga. Harga bisa ditetapkan sama, diatas atau dibawah pesaing.

4. Strategi harga berdasarkan kebutuhan konsumen, menentukan harga yang menyediakan nilai maksimal kepada pelanggan dan beranggapan bahwa pelangganlah yang menentukan dan sebagai titik tolak penetapan harga.

Promosi adalah suatu kegiatan yang dilakukan oleh perusahaan untuk mengomunikasikan manfaat dari produknya dan untuk meyakinkan konsumen agar membeli (Kotler dalam Rangkuti, 2009: 177). Sedangkan menurut Julian Cummins (Rangkuti, 2009 : 177) promosi adalah serangkaian teknik yang digunakan untuk mencapai sasaran penjualan atau pemasaran dengan penggunaan biaya yang efektif, dengan memberikan nilai tambah pada produk atau jasa baik kepada para perantara maupun pemakai langsung. Jadi promosi merupakan serangkaian kegiatan untuk mengomunikasikan, mencapai sasaran pemasaran dan memberikan nilai tambah produk agar konsumen mau membeli.

Pemasar mengembangkan promosi untuk mengomunikasikan informasi mengenai produk dan mempengaruhi untuk membelinya. Untuk menciptakan dan memelihara keunggulan pembeda dari pesaing maka produk dan merek membutuhkan promosi yang dapat dilakukan dalam beberapa jenis yaitu (Petter dan Olson dalam Rangkuti, 2009: 178) :

1. Iklan, penyajian informasi nonpersonal mengenai produk, merek, perusahaan atau toko yang dilakukan dengan bayaran tertentu untuk mempengaruhi efeksi dan kognisi konsumen.

2. Promosi Penjualan, rangsangan langsung yang ditujukan kepada konsumen untuk melakukan pembelian.

3. Penjualan Personal, komunikasi antara pembeli dan penjual untuk mempengaruhi keputusan pembelian seseorang atau sekelompok orang.

4. Publisitas, merupakan bentuk-bentuk komunikasi tentang perusahaan, produk, atau merek pemasar yang tidak membutuhkan pembayaran.

Kegiatan pemasaran tidak dapat lepas dari pemilihan dan pengelolaan saluran perdagangan yang dipakai untuk menyalurkan produk atau jasa dan juga untuk melayani pasar sasaran, serta mengembangkan sistem distribusi untuk pengiriman dan perniagaan produk secara fisik (Kotler \& Amstrong, 2012:62). Sedangkan menurut Ratnasari \& Aksa (2011:4) tempat berhubungan dimana lokasi yang strategis dan bagaimana cara penyampaian jasa pada pelanggan. Secara umum lokasi merupakan tempat dimana perusahaan menyampaikan barang atau jasa kepada konsumen.

Dalam penelitian ini, hasil uji validitas terkait faktor-faktor yang mempengaruhi persepsi anggota dalam memilih produk simpanan pada KSU Mikat Al Khidmah Purworejo dengan menggunakan SPSS versi 20 adalah sebagai berikut:

1. Kualitas Produk

Hasil uji validitas butir pernyataan kualitas produk $\left(\mathrm{X}_{1}\right)$ dapat dilihat pada tabel berikut.

Tabel 1. Hasil Analisa Validitas Butir Pernyataan

\begin{tabular}{|c|c|c|c|c|}
\hline Variabel & No Pertanyaan & r hitung & r table & Kriteria \\
\hline \multirow{2}{*}{$\begin{array}{c}\text { Kualitas } \\
\text { produk }\end{array}$} & 1 & 0,778 & 0,227 & Valid \\
\cline { 2 - 5 } & 2 & 0,764 & 0,227 & Valid \\
\cline { 2 - 5 } & 3 & 0,744 & 0,227 & Valid \\
\hline
\end{tabular}


Hasil uji validitas menunjukkan bahwa tidak ada butiran yang gugur karena syarat terpenuhi yaitu nilai koefisiensi korelasi item total $\boldsymbol{r}_{\text {hitung }}>0,227$ sehingga tiga butir pernyataan variabel kualitas produk $\left(\mathrm{X}_{1}\right)$ tersebut dinyatakan valid dalam menjelaskan variabelnya.

2. Harga

Hasil uji validitas butir pernyataan variabel harga $\left(\mathrm{X}_{2}\right)$ dapat dilihat pada tabel berikut ini.

Tabel 2. Hasil Analisa Validitas Butir Pernyataan

\begin{tabular}{|c|c|c|c|c|}
\hline Variabel & No Pertanyaan & $\mathrm{r}$ hitung & $\mathrm{r}$ table & Kriteria \\
\hline \multirow{3}{*}{ Harga } & 1 & 0,776 & 0,227 & Valid \\
\cline { 2 - 5 } & 2 & 0,775 & 0,227 & Valid \\
\cline { 2 - 5 } & 3 & 0,660 & 0,227 & Valid \\
\hline
\end{tabular}

Hasil uji validitas menunjukkan bahwa tidak ada butiran yang gugur karena syarat terpenuhi yaitu nilai koefisiensi korelasi item total $r_{\text {hitung }}$ lebih dari 0,227 sehingga tiga butir pernyataan variabel harga $\left(\mathrm{X}_{2}\right)$ dinyatakan valid dalam menjelaskan variabelnya.

3. Promosi

Hasil uji validitas butir pernyataan variabel promosi $\left(\mathrm{X}_{3}\right)$ dapat dilihat pada tabel berikut.

Tabel 3. Hasil Analisa Validitas Butir Pernyataan

\begin{tabular}{|c|c|c|c|c|}
\hline Variabel & No Pertanyaan & r hitung & $\mathrm{r}$ table & Kriteria \\
\hline \multirow{3}{*}{ Promosi } & 1 & 0,691 & 0,227 & Valid \\
\cline { 2 - 5 } & 2 & 0,833 & 0,227 & Valid \\
\cline { 2 - 5 } & 3 & 0,818 & 0,227 & Valid \\
\hline
\end{tabular}

Hasil uji validitas menunjukkan bahwa tidak ada butiran yang gugur karena syarat terpenuhi yaitu nilai koefisiensi korelasi item total $\boldsymbol{r}_{\text {hitung }}>0,227$ sehingga tiga butir pernyataan variabel promosi $\left(\mathrm{X}_{3}\right)$ dinyatakan valid dalam menjelaskan variabelnya.

4. Persepsi

Hasil uji validitas butir pernyataan variabel persepsi (Y) dapat dilihat pada tabel berikut.

Tabel 4. Hasil Analisa Validitas Butir Pernyataan

\begin{tabular}{|c|c|c|c|c|}
\hline Variabel & No Pertanyaan & r hitung & r table & Kriteria \\
\hline \multirow{3}{*}{ Persepsi } & 1 & 0,807 & 0,227 & Valid \\
\cline { 2 - 5 } & 2 & 0,829 & 0,227 & Valid \\
\cline { 2 - 5 } & 3 & 0,818 & 0,227 & Valid \\
\hline
\end{tabular}

Hasil uji validitas butir variabel persepsi (Y) menunjukkan bahwa tidak ada butiran yang gugur karena syarat terpenuhi yaitu nilai koefisiensi korelasi item total $r_{\text {hitung }}>0,227$ dan valid dalam menjelaskan variabelnya.

Uji Reliabilitas digunakan untuk mengukur konsistensi kuesioner sebagai indikator dari variabel. Dikatakan reliabel jika ukuran tersebut memberikan hasil yang konsisten. Reliabilitas diukur dengan menggunakan metode cronbach alpha (Arikunto dalam Supriono, 2014:45). Hasil olah data diinterprestasikan dengan tingkat keadaan koefisien korelasi sebagai berikut (Sugiyono: 110):

1. 0,80 sampai 1,000 adalah tinggi

2. 0,60 sampai 0,799 adalah cukup

3. 0,40 sampai 0,599 adalah agak rendah

4. 0,20 sampai 0,399 adalah rendah

5. 0,00 sampai 0,199 adalah sangat rendah 
Tabel 5. Hasil Uji Reliabilitas

\begin{tabular}{|c|c|c|c|}
\hline Variabel & Cronbach's Alpa & Cronbach's Alpa minimal & Kriteria \\
\hline Kualitas produk & 0,637 & 0,40 & Reliabel \\
\hline Harga & 0,583 & 0,40 & Reliabel \\
\hline Promosi & 0,686 & 0,40 & Reliabel \\
\hline Persepsi & 0,750 & 0,40 & Reliabel \\
\hline
\end{tabular}

Hasil uji reliabilitas menunjukkan koefisien cronbach's alpha seluruh variabel > cronbach's alpha 0,40 yaitu kualitas produk sebesar $(0,637)$, harga $(0,583)$, promosi $(0,686)$ dan persepsi $(0,750)>0,04$ sehingga dapat dikatakan bahwa butir-butir pertanyaan seluruh variabel dalam keadaan reliabel.

Uji regresi linear berganda digunakan untuk mengetahui pengaruh variabel yang diteliti yaitu kualitas produk, harga, promosi terhadap persepsi anggota dalam memilih produk simpanan pada KSU Mikat Al Khidmah Purworejo. Berdasarkan hasil analisis di atas, dapat dilihat bahwa persamaan regresi linear berganda adalah $\mathrm{Y}=-0,502+0,610 \mathrm{X}_{1}+0,112 \mathrm{X}_{2}+0,350 \mathrm{X}_{3}+\varepsilon$ dan dapat diinterpretasikan sebagai berikut:

1. Nilai konstanta -502. Jika variabel kualitas produk, harga, promosi, sama dengan nol, maka keputusan penyimpanan akan sebesar -502 point.

2. Koefisien regresi variabel kualitas produk (X1) 0,610. Jika kualitas produk meningkat satu point, maka keputusan penyimpanan meningkat 0,610 point.

3. Koefisien regresi variabel harga (X2) yakni 0,112. Jika harga meningkat satu point, maka keputusan penyimpanan akan meningkat 0,112 point.

4. Koefisien regresi variabel promosi $\left(\mathrm{X}_{3}\right)$ yakni 0,350 . Jika promosi meningkat satu point, maka keputusan penyimpanan akan meningkat 0,350 point.

Tabel 6. Persamaan Garis Regresi Linear Berganda Model Summary

\begin{tabular}{|r|c|c|c|c|}
\hline Model & $\mathrm{R}$ & $\mathrm{R}$ Square & $\begin{array}{c}\text { Adjusted } \mathrm{R} \\
\text { Square }\end{array}$ & $\begin{array}{c}\text { Std. Error of } \\
\text { the Estimate }\end{array}$ \\
\hline 1 & $.797^{\mathrm{a}}$ & .636 & .621 & .921 \\
\hline
\end{tabular}

a. Predictors: (Constant), x3, x1, x2

Coefficients $^{\mathrm{a}}$

\begin{tabular}{|r|r|r|r|r|r|}
\hline \multirow{2}{*}{ Model } & \multicolumn{2}{|c|}{$\begin{array}{c}\text { Unstandardized } \\
\text { Coefficients }\end{array}$} & $\begin{array}{c}\text { Standardized } \\
\text { Coefficients }\end{array}$ & \multirow{2}{*}{$\mathrm{T}$} & \multirow{2}{*}{ Sig. } \\
\cline { 2 - 4 } & \multicolumn{1}{|c|}{$\mathrm{B}$} & Std. Error & Beta & & \\
\hline (Constant) & -.502 & 1.208 & & -.415 & .679 \\
1 & .610 & .099 & .525 & 6.159 & .000 \\
x1 & .112 & .116 & .097 & .966 & .337 \\
x2 & .350 & .100 & .321 & 3.496 & .001 \\
\hline
\end{tabular}

a. Dependent Variable: $y$

Pada tabel di atas diketahui bahwa koefisien regresi (R) sebesar 0,797, berarti ada pengaruh variabel kualitas produk, harga dan promosi terhadap persepsi anggota sebesar 0,797.

Hasil pengujian hipotesis dalam penelitian ini adalah sebagai berikut:

1. Analisis Regresi Linier Berganda

a. Kualitas Produk, dari hasil analisis regresi linear berganda pada coefficients diketahui bahwa variabel kualitas produk berpengaruh signifikan positif terhadap persepsi anggota. Dengan nilai hitung variabel kualitas produk $0,000<0,005$ maka $\mathrm{H}_{1}$ diterima dan $\mathrm{H}_{0}$ ditolak. 
b. Harga, berdasarkan hasil analisis regresi linear berganda pada coefficient, variabel harga tidak berpengaruh signifikan dan negatif terhadap persepsi anggota. Dengan nilai hitung variabel harga $0,337>0,005$ maka $\mathrm{H}_{1}$ ditolak $\mathrm{H}_{0}$ diterima.

c. Promosi, berdasarkan hasil analisis regresi linear berganda pada coefficients dapat dikatakan bahwa variabel promosi berpengaruh signifikan dan positif terhadap persepsi anggota. Dengan nilai hitung variabel promosi 0,001 $<0,005$ maka $\mathrm{H}_{1}$ diterima $\mathrm{H}_{0}$ ditolak.

Hasil dari penelitian ini menunjukkan bahwa terdapat faktor-faktor yang mempengaruhi persepsi anggota, yaitu produk, harga dan promosi secara simultan (bersama-sama) berpengaruh sebesar 44,219 (nilai signifikan 0,000).

2. Uji t, dimaksudkan untuk mengetahui seberapa jauh pengaruh independen secara individual dalam menerangkan variabel dependen (Suliyanto, 2011: 62).

Tabel 7. Persamaan Garis Uji t Coefficients $^{a}$

\begin{tabular}{|c|r|r|r|r|r|}
\hline \multirow{2}{*}{ Model } & \multicolumn{2}{|c|}{$\begin{array}{c}\text { Unstandardized } \\
\text { Coefficients }\end{array}$} & $\begin{array}{c}\text { Standardized } \\
\text { Coefficients }\end{array}$ & \multirow{2}{*}{$\mathrm{T}$} & \multirow{2}{*}{ Sig. } \\
\cline { 2 - 4 } & \multicolumn{1}{|c|}{ B } & Std. Error & Beta & & \\
\hline (Constant) & -.502 & 1.208 & & -.415 & .679 \\
x1 & .610 & .099 & .525 & 6.159 & .000 \\
x2 & .112 & .116 & .097 & .966 & .337 \\
x3 & .350 & .100 & .321 & 3.496 & .001 \\
\hline
\end{tabular}

a. Dependent Variable: $y$

Untuk menguji kebenaran model regresi masing - masing variabel secara parsial dapat diperoleh dengan menggunakan uji t. Berikut akan dijelaskan pengujian masing - masing variabel secara persial:

a. Hasil Pengujian Hipotesis 1 Variabel Kualitas Produk

Hasil uji t variabel kualitas produk menunjukkan nilai $\mathrm{t}=6,159$ dengan nilai signifikan $0,000 \leq 0,05$. Dengan nilai signifikan dibawah 0,05 menunjukkan bahwa kualitas produk memiliki pengaruh yang signifikan dan positif terhadap persepsi anggota dalam memilih produk simpanan sehingga hipotesa 1 kualitas produk terbukti dalam penelitian ini.

b. Hasil Pengujian Hipotesa 2 Variabel Harga

Hasil uji $\mathrm{t}$ variabel harga menunjukkan $\mathrm{t}=0,966$ dengan nilai signifikan $0,337 \geq 0,05$ sehingga harga tidak berpengaruh signifikan dan negatif terhadap persepsi anggota dalam memilih produk simpanan sehingga hipotesa 2 harga terbukti dalam penelitian ini.

c. Hasil Pengujian Hipotesa 3 Variabel Promosi

Hasil uji $\mathrm{t}$ variabel promosi menunjukkan nilai $\mathrm{t}=3,496$ dengan nilai signifikan signifikan $0,001 \leq 0,05$, sehingga promosi memiliki pengaruh yang signifikan dan positif terhadap persepsi anggota dalam memilih produk simpanan dan hipotesa 3 promosi terbukti.

3. Uji F

Uji $\mathrm{F}$ digunakan untuk mengetahui variabel independen secara bersama-sama mempunyai pengaruh signifikan terhadap variabelnya. Hasil perhitungan regresi secara bersama-sama diperoleh pada tabel berikut ini: 
Tabel 8. Persamaan Garis Uji F ANOVA $^{\mathrm{a}}$

\begin{tabular}{|l|r|r|r|r|r|}
\hline \multicolumn{1}{|c|}{ Model } & Sum of Squares & Df & $\begin{array}{r}\text { Mean } \\
\text { Square }\end{array}$ & F & Sig. \\
\hline Regression & 112.459 & 3 & 37.486 & 44.219 & $.000^{\mathrm{b}}$ \\
Residual & 64.428 & 7 & .848 & & \\
Total & 176.887 & 7 & & & \\
\hline
\end{tabular}

a. Dependent Variable: $y$

b. Predictors: (Constant), $\times 3, \times 1, \times 2$

Pengujian pengaruh variabel bebas secara bersama-sama terhadap variabel terikat dilakukan dengan menggunakan uji $F$. Hasil perhitungan menunjukkan nilai $F_{\text {hitung }} 44,219$ dengan nilai signifikan sebesar $0,000 \leq 0,05$. Dengan nilai signfikan $<0,05$ maka secara bersama-sama variabel kualitas produk, harga dan promosi berpengaruh positif dan signifikan terhadap persepsi anggota.

Hasil penelitian sebagaimana diuraikan di atas, sejalan dengan beberapa hasil penelitian lain sebelumnya. Hafidz (2013:201) dalam artikelnya yang berjudul "Pengaruh Reference Group dan Marketing Mix Terhadap Minat menggunakan produk KJKS/ BMT di Kota Pekalongan, dari hasil penelitiannya menunjukkan bahwa produk, tempat/distribusi dan promosi masing-masing berpengaruh signifikan terhadap minat anggota untuk menggunakan produk-produk dari BMT. Sedangkan harga dan reference group tidak berpengaruh signifikan. Sedangkan secara simultan, semua aspek yaitu reference group, produk, harga, tempat/distribusi dan promosi berpengaruh signifikan positif terhadap minat anggota untuk menggunakan produk BMT.

\section{KESIMPULAN DAN SARAN}

Berdasarkan analisis mengenai faktor-faktor bauran pemasaran yang mempengaruhi persepsi anggota dalam memilih produk simpanan pada KSU Mikat Al Khidmah Purworejo, dapat disimpulkan beberapa hasl sebagai berikut:

1. Berdasarkan analisis regresi linear berganda diperoleh bahwa faktor-faktor bauran pemasaran yang mempengaruhi persepsi anggota dalam memilih produk simpanan yakni kualitas produk, harga dan promosi, dengan rumus:

$$
\mathrm{Y}=-0,502+0,610 \mathrm{X}_{1}+0,112 \mathrm{X}_{2}+0,350 \mathrm{X}_{3}+\varepsilon
$$

a. Nilai konstanta sebesar -0,502. Jika variabel produk, harga dan promosi sama dengan nol, persepsi anggota akan sebesar 0,502 point.

b. Koefisien regresi variabel kualitas produk (X1) yakni 0,610. Jika kualitas produk meningkat satu point, persepsi anggota meningkat 0,610 point.

c. Koefisien regresi variabel harga (X2) 0,112. Jika harga meningkat satu point, maka persepsi anggota akan meningkat sebesar 0,112 point.

d. Koefisien regresi variabel promosi $\left(\mathrm{X}_{3}\right)$ 0,350. Jika promosi meningkat satu point, maka persepsi anggota akan meningkat sebesar 0,350 point.

2. Hasil analisis menunjukkan $\mathrm{R}$ Square sebesar 0,636 maka $63 \%$ variabel persepsi anggota dapat dijelaskan oleh variabel kualitas produk, harga dan promosi, sedangkan sisanya $37 \%$ dijelaskan oleh variabel lain diluar penelitian ini yakni lokasi, proses, pendukung fisik dan orang.

3. Berdasarkan uji t diketahui bahwa kualitas produk berpengaruh signifikan dan positif terhadap persepsi anggota. Maka semakin meningkat kualitas produk, persepsi anggota juga meningkat. Selanjutnya yaitu harga tidak berpengaruh signifikan dan negatif terhadap persepsi anggota dalam memilih produk simpanan, artinya bahwa semakin murah harga tidak merubah persepsi anggota mengenai harga tersebut. Sedangkan promosi berpengaruh signifikan dan positif 
terhadap persepsi anggota, berarti semakin banyak promosi yang dilakukan maka semakin meningkat persepsi anggota.

4. Berdasarkan uji F menunjukkan bahwa secara bersama-sama variabel kualitas produk, harga dan promosi mempunyai pengaruh yang positif dan signifikan terhadap persepsi anggota. berikut :

Menindaklajuti hasil penelitian maka ada beberapa implikasi manajerial dan saran sebagai

1. Pengaruh Kualitas Produk Terhadap Persepsi Konsumen

Hasil penelitian menunjukkan bahwa kualitas produk dapat berpengaruh secara langsung dan signifikan terhadap persepsi anggota pada KSU Mikat Al Khidmah. Tindakan yang harus dilakukan untuk mendapatkan kualitas produk agar meningkat dari sebelumnya yaitu dengan memaksimalkan kualitas untuk masing-masing produk pada koperasi. Selain itu adanya kesesuaian antara persyaratan penentuan kebutuhan anggota sejak awal dan setiap saat. Maksudnya adalah kesesuaian antara informasi yang tertera dalam brosur dan informasi yang diberikan dengan realisasi di setiap produknya. Untuk dapat lebih di kenal oleh masyarakat dapat pula diadakan promo mengenai masing - masing produk melalui hadiah tertentu untuk pendaftar pertama, promo hari besar keagamaan, ulang tahun lembaga dan lainnya.

2. Pengaruh Harga Terhadap Persepsi Konsumen

Hasil penelitian menunjukkan bahwa harga tidak berpengaruh secara langsung dan signifikan terhadap persepsi anggota. Hasil ini mengidentifikasi bahwa semakin murah harga tidak merubah persepsi anggota. Harga tidak berpengaruh terhadap persepsi anggota dikarenakan harga untuk setiap produk pada koperasi terjangkau di kalangan menengah kebawah yang mana kalangan tersebut yang mendominasi anggota pada koperasi. Untuk itu harga di setiap produk agar dipertahankan guna untuk menambah minat masyarakat.

3. Pengaruh Promosi Terhadap Persepsi Konsumen

Hasil penelitian menunjukkan bahwa promosi berpengaruh secara langsung dan signifikan terhadap persepsi anggota. Promosi merupakan salah satu faktor yang sangat penting dalam sebuah instansi khususnya KSU Mikat Al Khidmah Purworejo. Tanpa adanya promosi masyarakat luas tidak tahu akan keberadaan koperasi. Tindakan untuk mendapatkan faktor promosi yang maksimal dalam mempengaruhi persepsi konsumen yaitu membuat banner, ikut serta dalam acara Expo, promosi khusus dengan iklan di media massa setak serta radio.

\section{DAFTAR PUSTAKA}

Ginting, Nembah F. Hartimbul. 2011. Manajemen Pemasaran. CV Yrama Widya: Bandung.

Hafidz, M. 2013. Pengaruh Reference Group dan Marketing Mix Terhadap Minat Menggunakan Produk KJKS / BMT di Kota Pekalongan. Jurnal Penelitian, 10(2), 181-204.

Haryanto \& Hartono, Ruslijanto \& Datu, Mulyono. 2006. Metodologi Penelitian Kesehatan dengan Contoh Bidang Ilmu Kesehatan Gigi. Buku Kedokteran EGC: Jakarta.

Kalsum, Eka Umi. 2010. Pengaruh Strategi Bauran Bemasaran Terhadap Keputusan Mahasiswa Memilih Perguruan Tinggi Swasta Di medan. Jurnal Ilmiah Abdi Ilmu, 3, (1), 331.

Kotler, Philip. 2002. Manajemen Pemasaran Perspektif Asia. Andi: Yogyakarta.

Nitisusastro, Mulyadi. 2010. Kewirausahaan dan Manajemen Usaha Kecil. Alfabeta: Bandung.

Rangkuti. Freddy 2009. Strategi Promosi Yang Kreatif \& Analisis Kasus Integrated Marketing Communication. Gramedia Pustaka Utama: Jakarta.

Ratnasari, Ririn Tri \& Mastuti H Aksa. 2011. Teori dan Kasus Manajemen Pemasaran Jasa. Ghalia Indonesia: Bogor.

Rudianto. 2010. Akuntansi Koperasi. Erlangga: Jakarta.

Subandi. 2013. Ekonomi Koperasi. Alfabeta: Bandung.

Suharno \& Yudi Sutarso. 2010. Marketing in Practice. Graha Ilmu: Yogyakarta.

Suliyanto. 2011. Ekonometrika Terapan: Teori \& Aplikasi dengan SPSS. Andi: Yogyakarta.

Supriono. 2014. Analisis Faktor-Faktor yang Mempengaruhi Penggunaan System Informasi Akuntansi Bagi Usaha Kecil dan Menengah. Tesis: Kebumen. 